
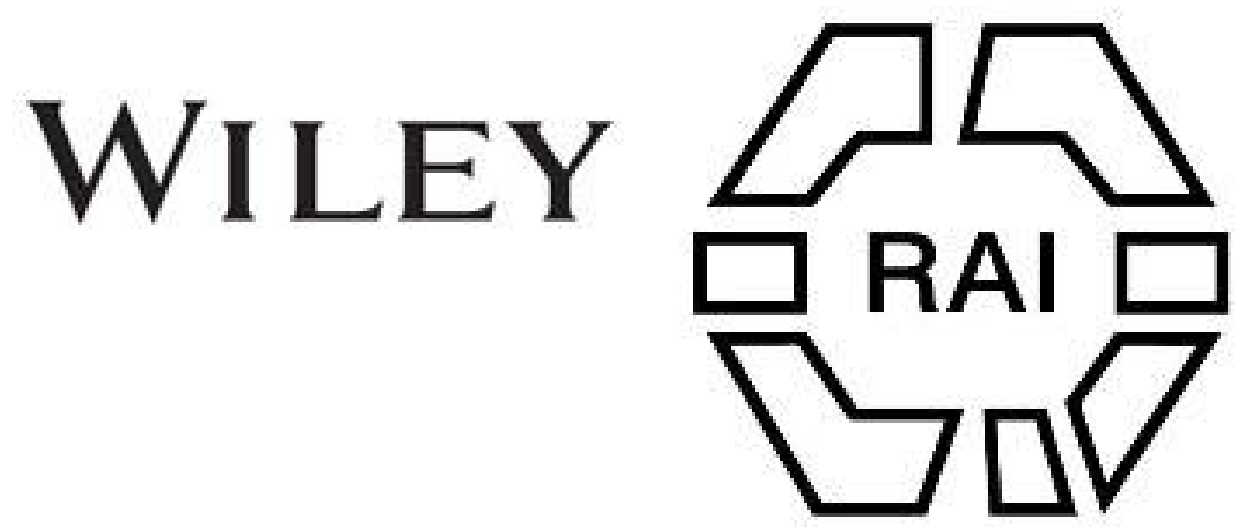

\title{
45. Muhammadan Betrothal Observances in the Punjab
}

\section{Author(s): H. A. Rose}

Source: Man, Vol. 17 (Apr., 1917), pp. 58-62

Published by: Royal Anthropological Institute of Great Britain and Ireland

Stable URL: http://www.jstor.org/stable/2788146

Accessed: 25-06-2016 14:50 UTC

\section{Your use of the JSTOR archive indicates your acceptance of the Terms \& Conditions of Use, available at}

http://about.jstor.org/terms

JSTOR is a not-for-profit service that helps scholars, researchers, and students discover, use, and build upon a wide range of content in a trusted digital archive. We use information technology and tools to increase productivity and facilitate new forms of scholarship. For more information about JSTOR, please contact support@jstor.org.

Wiley, Royal Anthropological Institute of Great Britain and Ireland are collaborating with JSTOR to digitize, preserve and extend access to Man 
of the "prophet," it is the more gratifying that Mr. Talbot by his promptness and energy was able to rescue as much as he has done. By his timely intervention and generosity the British Museum and the Oxford Museum have acquired a number of valuable accessions.

HENRY BALFOUR.

Punjab.

Rose.

Muhammadan Betrothal Observances in the Punjab. Rose.

By H. A.

\section{Section 1.-Terminology.}

Among Muhammadans "betrothal" is known as mangewä, mangnī, mangan (and other forms of that word," which literally means "asking" or "begging"). It is also called sagã̄, especially in the south-east, and kurmāī. $\dagger$ Another term is ropn $\bar{a}$, which literally means the present or token consisting of seven dried dates and various other things sent by a (Hindu) girl's father to his prospective son-in-law at or before the betrothal. It corresponds to the shagun $\ddagger$ among the higher castes, e.g. in Hoshiarpur. The Arabic word nisbat is also used, chiefly in the towns. Another common term is nātta or nāt $\bar{a}$, which has a somewhat derogatory meaning, so that $n \bar{a} t \bar{a}$ den $\bar{a}$ means to give a girl in marriage, an admission of inferiority in status. The bridegroom is styled mangedar or mangetar, $\$$ a term also applied to a betrothed girl, while bendha is used in the south-east. In the north-east he is called dülo, or dulhā, or naushāh,\|nausho, nausā, or naudho being variant forms of the latter word, and in Gujrānwālā lārā is also used. In the Talagang tahsil of Jhelum he is called nadha and his bride is kuri, literally a girl or a virgin. In the south-west ghot is in common use.

The bride is correspondingly bendhāni, dulhän, or kwār in the south-west, and after she is married nodh or bahü. The latter term means literally son's wife.

In the Pashto of Peshāwar bethothal is called koyidan. The bridegroom is dalled changhūl and the bride chunghala. During the days of marriage the changhül and chunghal $\bar{a}$ are respectively called khāwand and $n \bar{a} w \bar{\imath}$.

The boy's father is particularly, and the boy's kinsmen are generally, called putretu. Similarly the girl's father or party is dheta.

\section{Section 2.-Preliminaries in Betrothals.}

In Arabia, it is said, marriage is usually adult, and it is not regarded as indecent that the bridegroom should see his future wife, but the seclusion of women in India renders this impossible, at least among the better classes. In consequence a mâshshâta or go-between is often employed to spy ou the girl and report on her looks, etc., to the boy's people. These go-betweens assume various disguises, such as cloth-sellers, in order to obtain access to the girl's house, while, on the other hand, a girl is not infrequently substituted for the one seen and reported on by the go-between. Unpleasantness not unnaturally frequently results from such a deception. In theory Muhammadan law attaches great importance to mutual consent in marriage, but in India the practice is very often opposed to allowing even grown-up girls to express any opinion on a proposed betrothal. In fact, among the Muhammadans of Delhi there is a custom of pre-natal betrothal which is called thîkrî ki mâng, ${ }^{* * *}$ because, if a girl be born according to anticipation, the boy's mother drops a rupee into the girl baby's bath or mixes sugar candy in the ghutti given to her, as an earnest

\footnotetext{
* E.g. mangarrn in the Rãjanpur tahsīl of Derā Ghāai Khān.

$\dagger$ Fr. kuram, "a relation by marriage."

† Or shagan, lit. "an omen."

$\$$ Mangenda, fem. mangendi is also used.

|| This word appears to mean "new king."

I See Maya Singh's Punjabi Dictionary. s.t.

** Fr. thîkrá. an carthen vessel. Mâng, asking.
}

$\left[\begin{array}{ll}58 & ]\end{array}\right.$ 
of the betrothal contract this ratified. In Rohtak a boy's mother or any near kinswoman may drop a rupee into the vessel used by a midwife, and by so doing apparently bespeaks the new-born girl for her son. The betrothal is there and then announced and congratulations are exchanged.

Contrary to the usual practice amongst Hindus, the proposal among Mubammadans comes almost invariably from the boy's side. 'The term $b \hat{a} t \hat{a} n \hat{a}-b \bar{a} t-j \bar{a} n \bar{a}$, to propose, is used when negotiations are. opened by the boy's people. When both sides are satisfied as to the suitability of the match a day is fixed "for sweetening the

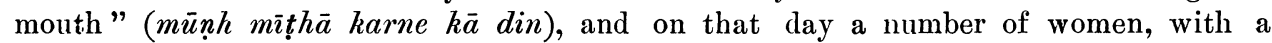
few men of the boy's family, go to the girl's house to perform the betrothal rites." In the Sangrūr tahsil of Jind the request by the boy's father is called $d h u k$ and he visits the girl's father in the evening. 'The $d u \bar{a}-i$-khair is then observed, the senior member of the boy's party commencing the prayer.

In Dera Ghāzī Khān the negotiations which precede a betrothal are called $s a w \bar{a} l$ or "request," and may take place a month or more before the betrothal is solemnised.

The negotiations are, however, not infrequently opened by the girl's people among the rural classes who are converts from Hinduism. Thus among the Meos of Gurgaon the girl's party first visits the boy's father, and reaches his house on the evening of an anspicious day in the lunar month. If they find the boy to their liking they are feasted, after giving a rupee each to the boy, his father, brother, father's sister, and his mīrāsi and barber. The party is also feasted on the second and third days, after which it sets out for its home, giving the boy's parents Rs. 11 or 22 as a farewell gift. Of this sum a rupee is left in the vessel in which it was presented; the barber and mirrāsi take one rupee and the balance is given to the poor. The girl's father in turn gives a rupee to the boy's father. This is called mila $p$. Among other Muhammadans the observances vary. A ring or two is often sent to the boy, with other presents, and the rings are put on by the boy amongst his assembled kinsmen. $\dagger$ A ring is often presented in sugar, and the kinsmen feasted with more or less ceremony.

When such a negotiation is initiated by the girl's father certain special observances may occur. 'Thus in Siālkot a mīrāsi, barber, or even a Brahman, is sent to the putreta or boy's father, and when he reaches his house a little oil is dropped on the threshold before he enters it. This observance is called tel dālnāa. The putreta's lägīs also assemble, and the dhetā's lāg $\bar{\imath}$ is given some sugar in a plate, from which he takes a little in his mouth. This observance is called munhl juthlawna or juthālnā or juthalnna $=$ to defile : P.D., p. 522. Then the lāgi is given khichri. He eats some of it and drops a rupee and some copper coins in the plate. These are distributed among the putretā's lägīs. Next day the boy's kinsmen feast the $l \bar{a} g \bar{\imath}$ on rice and sugar or mutton and bread. At the $z u h r$ prayer carpets are spread in the boy's house and the whole brotherhood assemble. The boy is seated in front of the $l \bar{a} g \bar{\imath}$, who gives him from Re. 1 to Rs. 25 as well as a date or sugar candy to eat. Then he exchanges congratulations with them and observes the niyat khair. After this all present congratulate the boy's father. The dhetā's lāgi presents a sum varying from Re. 1 to Rs. 11 for distribution among the boy's kamins. The boy's people also distribute tapāsās of sugar among the people on this occasion. Some well-to-do Jāt and Rājput families also send a camel, a horse, and ornaments such as bangles or butkiān $\rangle_{\ddagger}^{+}$for the boy's mother. This is called tikka bhejnā. On

* This paragraph applies to Delhi city.

$\dagger$ The barber is given rice, $g h i$, and sugar, but nothing containing salt should be offered him on this occasion.

$\$$ Budki, a gold coin worth Rs. 5 : P.D., p. 168. 
this occasion drums, \&c., are beaten in the boy's father's house. 'The persons present on the occasion give a rupee each to the boy's father to be given to the lāgi. On the $l \bar{a} g \bar{\imath}$ 's departure the boy's father gives them as wadāigi from Rs. 4 to Rs. 8, which is divided into four shares, three being given to the lāgis named above and the fourth to the $l \bar{a} g \bar{\imath}$ of the maternal relatives. No mention is made on this oecasion regarding the date of the wedding.

A very few wealthy families in Gujrānwālā also observe this custom of sending a $t_{i k k} \bar{a}$, but in a slightly different way. It consists in sending a barber, a mìrāsi, a Brahman, and a tailor, with a horse, a camel, clothes for the boy and his parents, a gold finger-ring for the boy, Rs. 21 in cash, five lumps of candy, and some dried dates. On the arrival of the lāgis named, the boy's father invites his kinsfolk to his house and displays the gifts mentioned. Congratulations are then exchanged and tapāshās distributed among those present. Rs. 2 to 5 are given to each of the bride's $l \bar{a} g \bar{\imath} s$, and they are then sent back. Various intermediaries are employed in the preliminary negotiation. Thus in the Bhakkar tahsil of Mīanwāli, on the Indus, a Sayyid, maulavi, faqìr, or any respectable elder, is sent to the girl's father by the boy's to make a request (dhuknā) for her hand. If it is meant to accept it an ambiguous answer is given until the proposal has been repeated four or five times. Meanwhile the boy's kinswomen begin visiting the girl's family with presents, and finally the offer is accepted provided the parties be related or the boy's father promises compensation or a girl in exchange. In the Leia tahsil of this district the leading families, almost all Sayyids and dominant Baloch, the first step to take when a boy reaches a marrying age is to send a $d h u k$ or embassy of picked members of the family to the girl's father. His refusal will be definite, not to say abrupt, but his acceptance ostensibly reluctant and well-considered. The families now begin to associate, but the girl veils herself from all the males of her intended husband's family.

But in Hazāra generally no intermediary is employed save the barber, and he is not called when the parties belong to the same brotherhood, for then the womenfolk arrange matters. In Peshawar an elderly kinswoman of the boy acts as daläla, or go-between, and it is only when she has succeeded in securing a bride for him that a jirga of Sayyids and ulmãs is sent to the girl's parents. If they are wealthy they put off the jirga twice or thrice before finally consenting.

Even after these preliminary negotiations the final betrothat does not always take place at once. Thus in Bhakkar and Leia a few days after the negotiations have closed the boy's people go to the girl's house and formally present her father with a few gold or silver ornaments for her use, and after the $d u \bar{a}-i-k h a i r$ has been repeated distribute sweetstuff. This observance is called nishānī, or "token." In Bhakkar the boy's father is said to place a ring on her finger and a bhochhan or sheet on her head, and this is called nishäni. The betrothal follows a month or two later. But among the Utmānzais in Hazāra the nishānn̄ only precedes the betrothal by a couple of days, and is observed in rather a curious way : the boy's party takes presents to the girl's village. After nightfall they are invited to her house, and the mirrāsi brings a plate, into which the boy's father puts the ornaments. Of these the girl's father takes two or three by way of nishāni, and then the betrothal is announced, the $d u \bar{a}-i$-khair recited, and congratulations exchanged. The $m \bar{r} \bar{a} s \bar{s}$ 's fee for this service varies from Rs. 4 to 8 , twice that of the barber, so the part he plays must be regarded as important. 'The boy's teacher gets from Rs. 1 to 5. Among the Jadūns in this district the nishānī appears to be the betrothal itself, for when a match has been arranged the boy's father sends food-called jirga $k \bar{\imath}$ roti-to the girl's and then pays a visit (jirga), which must be made on a Monday or a Friday, and by night, to her house. The jirga or visitors are then 
fed, and a barber presents sugar in a plate to one of its members. He drops Rs. 30, 50, or whatever the girl's father demands, into it, and the barber carries it into the house. The girl's father accepts part of the money and returns the rest. The $d u \vec{a}-i$-khair is then recited, and a rupee* given to the mosque. A barber then gives the boy's kinsmen in a cup (katora), into which they drop a rupee. In another cup mehndi is brought, and this is applied to each man by way of nishāni. Another rupee is dropped into this cup also. Within a week of the jirga's departure, some of the boy's kinsmen take a sweetmeat called pakwān to the girl's house, where they spend the night. The return visit is called milni. At the next Id the boy's parents send the girl clothes and uncooked food, with an ornament if wellto-do, and similar presents are sent on every $\overline{\mathrm{I}} \mathrm{d}$ and Shab Barāt until the wedding.

In Peshāwar also the nishāni is the nāta or betrothal. When the last jirga has obtained a definite promise of the girl, a body of the boy's kinsmen go to the girl's house, and take one to seven ornaments with them as nishāni. When they arrive they are seated on a carpet, and the barber brings a patnos into which each puts some money. The ornaments, too, are put in, and then the patnos is sent inside to the girl's womenfolk. The amount of money agreed upon and the nishanni are kept, and the patnos with the balance sent out again to the boy's kinsmen. The betrotbal is completed by the father paying certain fees to the barber, the imãm of the mosque, and the mutrib. On the third day after this the girl's parents send the boy a ring and a suit of clothes-a gift called jor $\vec{a}$-and at each fair and festival his parents send her presents till the wedding.

In the Utmānnāma Tappa of Peshāwar the nishānī observance appears in all essentials under the name of $t h \bar{a} l$-the plate in which the ornaments for the girl are placed. The thāl ceremony concludes with the return, it is said, of all the ornaments and cash offered. However this may be, at its close each person present drinks some sharbat and puts some mehndi on his hands-an observation called ghünt, which is held to make the betrothal binding. The third day after the betrothal the girl's kinswomen go to the boy's house for two or three days, and when they depart his parents give his future mother-in-law and sister-in-law a rupee each "by way of parona." This observance is called channa arta. Again, two or three days later the bridegroom, with two or three friends and females, goes by night to his father-in-law's house taking with him sweetmeats and cash Rs. 2 to 10 . The party are feasted and then the bridegroom puts the money into the plate and sends it with the sweetmeats to his mother-in-law as salam āna. Shortly afterwards the bride's parents come, flinging jets at him, and sprinkle scented water over him. This is called $u b \bar{a}$ achwal. At each fair and festival after these ceremonies the bridegroom sends gold or silver ornaments for the bride.

In the Chakwāl tahsil of Jhelum a very similar custom exists. To ratify the understanding already arrived at, the boy's father goes one day to the girl's and presents him with sweetstuff and Rs. 21 in cash in the presence of her brotherhood. Her father accepts from Re. 1 to Rs. 5, rarely taking the whole, and coloured water is sprinkled over the whole of the boy's party. The $d u \bar{a}-i$-khair is recited at night, and they return next day. This is called nishāni rakhna. The boy does not accompany the party on this occasion. On the first $\overline{\mathrm{I}} \mathrm{d}$ after it, the boy's father sends presents for the girl, and if he is well-to-do he sends clothes to her mother and sister as well-when the gift would be called dhā̄ tewar den $\bar{a}$, "to gift 3 " (literally $2 \frac{1}{2}$ ) sets of clothes." The fathers may also exchange gifts of clothes, but if the bride's parents only receive garments for her they need only give sweetmeats in return. If this gift is brought by a barber the girl's father gives him a rupee. a turban, and a kurta-an observance called kapre denō. At the next Id 
clothes, \&c., are ouly sent to the girl. In Talagang tahsīl the nishāni is merely a present of Rs. 5 in cash and as many paos of sugar male. it seems, at betrothal. So, too, in Haripur tahsill, in Hazăra, it is an ornament given to the girl at the mangeva. Finally, in Hoshiārpur, at least among the Paţhāns, we find the nishāni following the solemn betrothal, at which a maulavi invokes the niyat khair twice and the girl's father gives dried dates and sugar to the boy's party by way of shagun. The contract having thus become irrevocable, some date of the lunar month is fixed for the nishāmin, which merely consists in the interchange of presents, feeing of lāgis, and the payment by the girl's father of sufficient money to buy the boy a ring:"

H. A. ROSE.

\section{African Relutionships.}

Seligman.

\section{The Relationship Systems of the Nandi Masai and Thonga. By 46
Brenda $Z$. Seligman.}

The following notes on the relationship systems of the Thonga, Nandi, and Masai are based upon the published works of M. H. Junod † and Mr. H. C. Hollis. The comparison shows some striking points of resemblance, which can be explained by the prevalence among all three peoples of a particular type of marriage, apparently dependent on the payment of the bride price. Among the 'Thonga this marriage, i.e., with the wife's brother's daughter, takes place at the present day. $\$$ We have no record of it among the Nandi or Masai, yet so close is the correspondence in the use of the relationship-terms involved, that I can only conclude that if this marriage does not take place at the present day it must once have been the custom.

Those persons to whom A can trace relationship through the father are indicated by solid sex signs.

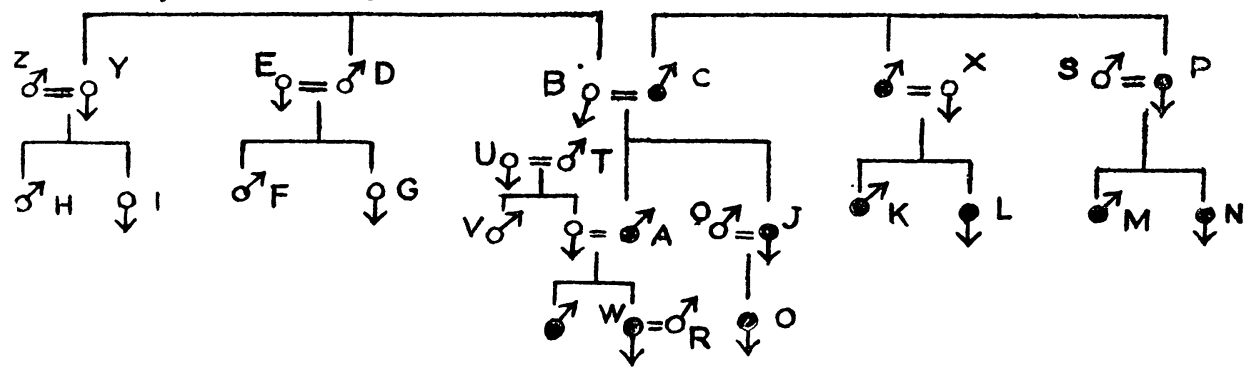

Nandi.

Thonga.

Masai.

A calls I), E, F, imamet

$\mathrm{D}$ calls A lakwet (son)

$A$ calls $B$ and $G$ kamet

(mother).
A call: D and $\mathrm{F}$ malume or A calls D and $\mathrm{F}$ ol-apu kokuana.

D calls A ntukulu (grandson)

$A$ calls $B$ and $G$ mamana

(mother).

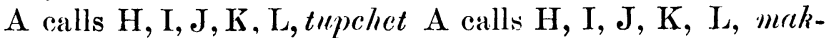
wabu.

A calls $\mathrm{M}$ weirit-ap-chepto

A calls $\mathrm{N}, \mathrm{O}$, lakwet-ap-

taptel.

* In Leia a few days after the betrothal a date is fixed and on it the son's party, with some relations and friends. go to the grrl's house, and before the assembly present her father with a few silver or gold ornaments for her personal use. After saying the dua khuir and distributing sweetmeat they return home. This is called nishāui, lit. "a mark of sccuring union."

$\dagger$ The Life of " Sinth dfrican Tribe. Neuchatel, 1912.

$\ddagger$ The Nandi: also, "Note on the Masai System of Relationship and other matters connected therewith." .Journ. Roy. Anthr. Inst., Vol. xl. p. 473.

$\$$ Junod, Op. cit., pp. 232-233. 